laki. Ketetapan agamis yang telah menjadi kesepakatan para ulama atau ijma digugat atau dikritik, seperti iddah dan talak mulai selalu dipertanyakan. Kenapa hanya perempuan saja yang harus menjalani iddah? Dan kenapa hanya laki-laki saja yang memegang kendali talak atau perceraian?

Emansipasi alah Barat ini melahirkan gagasan dan gerakangerakan perempuan menuntut haknya, seperti persamaan dalam menduduki suatu jabatan, persamaan hak dan kewajiban, dan kegiatan keseharian. Bahkan juga persamaan dalam kegiatan olah raga, sehingga jika dulu olah raga tinju dan bola kaki hanya merupakan khas laki-laki, maka sekarang - sebagai dampak emansipasi - kegiatan tersebut juga merupakan permainan kaum perempuan. Demikian pula dalam soal pekerjaan; jika dulu pekerjaan berat didominasi oleh kaum pria maka sekarang kaum prempuan pun telah memasuki sektor ini. Sehingga selolah-olah tidak ada lagi batasan dan skat-skat pekerjaan, budaya, pergaulan, tanggung jawab, profesional, dan lain sebagainya; semua sektor bisa dimasuki oleh kedua jenis insan ini.

Gagasan feminime model Barat ini tidak hanya memasuki ruangruang budaya dan pergaulan tetapi juga memasuki hal-hal yang bersifat dogmatis dan pemahaman keagamaan. Ia, misalnya, berdampak kepada perubahan atau modernisasi pemahaman yang sudah tertanam dengan mapan dalam tatanan masyarakat Islam semenjak lama. Hal-hal yang telah disepakati selama ini sekarang digugat oleh kaum feminisme ini. Aminah Wadud, seorang tokoh feminisme muslimah Amerika, menegaskan; wanita itu benar-benar sejajar dengan laki-laki, jika laki-laki wajib salat Jum'at maka wanita juga wajib melaksanakannya dan jika laki-laki tidak wajib berjilbab baik dalam salat maupun di luar salat maka wanita juga demikian. Bahkan pengaturan saf ketika salat, laki-laki disamakan dengan wanita. Untuk merialisasikan pemahamannya ini, Aminah melakukan salat Jum `at di mana dia bertindak selaku khatib dan imam sedangkan makmumnya terdiri dari laki-laki dan prempuan.

\section{MODEL EMANSIPASI QUR'ANI TERHADAP KAUM PEREMPUAN}

Kadar M. Yusuf

Fakultas Tarbiyah dan Keguruan UIN Suska Riau
The Model of Woman's Emanticipation in the Qur'an: The notion of women's emancipation is first emerging from the Koran. The Scripture has a lot of ideas and views on the emancipation of women. Views of the Koran on the improvement of women is not only limited to the ideas of course, but the Koran produces many of the provisions that must be followed in order to improve upon women. What is desired by the Koran to the condition of women is not an absolute equality between men and women. However, the Koran continued to see each of them has different tasks and functions. Both must carry out the functions and duties of each, for harmony and happiness together. Then the gender difference in the Koran is not negative discriminatory as alleged many scholars. Gender distinction in the Koran is distinction of partners or joint.

Keywords : Emancipation, Women, Men and Partners.

\section{Pendahuluan}

Emansipasi perempuan adalah suatu gerakan pemikiran sekali gus aksi yang bertujuan memberikan pembebasan kepada kaum wanita dan melepaskan mereka dari pengekangan dan pembatasan untuk maju. Di dunia Timur dewasa ini, orang mengenali bahwa emansipasi peremuan itu dibangun oleh Barat terutama kelompok feminisme yang tidak banyak membaca perjalanan sejarah Islam dan penurunan Alqur'an. Sehingga model emansipasi Barat, yang sekuler, nyaris semuanya diadopsi. Sebagai akibatnya, banyak kaum wanita dan kaum feminisme menuntut persamaan dan kesetaraan mutlak dengan laki- 
tulang rusuk yang bengkok dan Hadis larangan berpuasa sunat atas seorang perempuan, di mana suaminya tidak rida. Pada hal sanad Hadis tersebut jelas sahih ${ }^{2}$. Kedua melakukan penakwilan-penakwilan terhadap Hadis yang secara tekstual dimaknai "merendahkan kaum perempuan". Hal yang sama juga diperlakukan terhadap ayat-ayat Alqur'an, seperti penafsiran ayat:

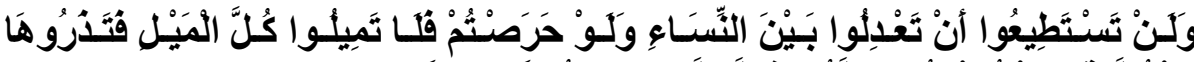

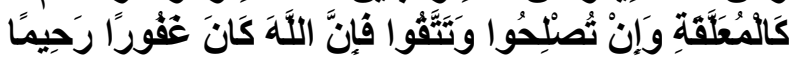

Artinya: Dan kamu sekali-kali tidak akan dapat berlaku adil di antara isteri- isteri (mu), walaupun kamu sangat ingin berbuat demikian, karena itu janganlah kamu terlalu cenderung (kepada yang kamu cintai), sehingga kamu biarkan yang lain terkatung-katung. Dan jika kamu mengadakan perbaikan dan memelihara diri (dari kecurangan), maka sesungguhnya Allah Maha Pengampun lagi Maha Penyayang ${ }^{3}$.

Banyak kalangan aktivis perempuan yang memaknai ayat ini sebagai tidak bolehnya poligami, sebab bagaimanapun juga seorang laki-laki tidak mungkin dapat berlaku adil terhadap isteri-isterinya. Sehingga ayat ini, menurut alur pemikiran mereka, bertentangan dengan ayat lain (QS 4:3) yang membolehkan seorang laki-laki berpoligami. Artinya, Alqur'an membolehkan sesuatu yang mustahil dilakukan. Binti Syati' membantah pendapat itu. Menurutnya, ayat ini tidak ada kaitannya dengan larangan poligami. Tidak mungkin terjadi pembolehan di satu sisi dan pelarangan di sisi lain.

Pernyataan ketidaksanggupan laki-laki berbuat adil terhadap para isteri dalam ayat di atas adalah membagi perasaan cinta kasih terhadap masing-masing mereka. Bukan pembagian hak-hak yang bersifat fisik

${ }^{2}$ Hadis itu ialah : لاتصوم المرأة وزوجها شاهد يوما من غيرشهر رمضان إلا بإننه. AlTirmizi mengomentari Hadis ini dalam sunannya; bahwa Hadis ini termasuk Hadis Hasan Sahih (al-Tirmizi, Abi Isa Muhammad bin Isa bin Surah. Sunan al-Tirmizi Jilid II. Bandung; Maktabah Dahlan. t.th. hlm. 140. Hadis ke-779.

$$
{ }^{3} \text { QS } 4 \text { (al-Nisä); } 129 .
$$

Pemikiran seperti ini tidak hanya memasuki wilayah pengamalan agama, tetapi juga merembes kepada corak atau model pengkajian terhadap sumber ajaran Islam, baik Alqur'an maupun Hadis. Muncul bentuk penafsiran yang berbeda dari penafsiran kaum salaf dan jumhur mufassir, seperti penafsiran Aminah terhadap ayat 34 surat alNisä'; kalimat al-rijāl qawwämūna 'alà al-nisä' tidaklah dimaksudkan bahwa superioritas itu melekat pada setiap laki-laki secara ototmatis. Hal itu hanya bersifat fungsional, yaitu selama yang bersangkutan memilki kreteria yang telah ditetapkan Alqur'an yang meliputi memiliki kelebihan dan memberikan nafkah. Dan ini jelas tidak hanya berlaku pada kaum laki-laki melainkan juga bagi perempuan ${ }^{1}$. Aminah lebih menekankan pada kata wa bimā anfaqū tidak pada al-rijäl sebagai jenis kelamin, sehingga al-rijäl dimaknai secara majazi bukan hakiki. Demikian pula pemahaman terhadap Hadis, sehingga muncul pandangan sinis terhadap Hadis-hadis mengenai gender yang secara harfiah menganggap kaum laki-laki itu super atau lebih utama dari kaum perempuan. Akhirnya, muncullah kritik terhadap matan Hadis (naqd al-matn), walaupun Hadis itu termuat dalam kitab-kitab sahih. Karena itu, kajian kritik matan banyak dikembangkan terutama oleh kaum feminisme. Kesahihan sebuah Hadis tidak hanya didasarkan atas ketersambungan sanad, ketsiqahan, dan dhabitnya para rawi tetapi juga didasarkan atas keseimbangan antara kaum perempuan dan kaum lakilaki. Jika suatu matan Hadis, misalnya, secara harfiah tidak memihak kepada kaum perempuan maka Hadis itu dianggap tidak sahih dan tidak boleh dijadikan sandaran hukum.

Ada dua model pemahaman kaum feminisme terhadap Hadis: Pertama melakuakan kritik matan, sehingga yang dijadikan kreteria kesahehan sebuah Hadis tidak hanya berpatokan pada keadaan sanad tetapi juga pesan-pesan yang terkandung dalam Hadis tersebut. Hal ini seperti kritik terhadap Hadis tentang penciptaan perempuan dari

${ }^{1}$ Aminah Wadud dalam Didin Syafruddin. Argumen Supremasi atas Perempuan Penafsiran Klasik QS al-Nisä': 34. Jurnal Ilmu dan Kebudayaan; Ulumul Qur'an. Nomor 5 dan 6, Vol V. 1994. Edisi Khusus 5 tahun UQ. 


\section{Paradigma Masyarakat Global Sebelum Alqur'an Diturunkan}

Sejarah perjalanan hidup umat manusia memperlihatkan berbagai ragam budaya dan kerangka berpikir; antara satu bangsa dengan bangsa lainnya mempunyai adat atau kebiasaan yang berbeda. Perbedaan tersebut berangkat dari resam, sistem dan kepercayaan yang telah berlaku di tengah-tengah mereka. Namun kepercayaan, sistem, dan resam itu bisa berubah seiring dengan perkembangan pemikiran dan masuknya kepercayaan dan sistem lain. Perubahan tersebut bisa disebabkan oleh lemahnya pondasi bangunan sistem yang berlaku, atau rapuhnya kepercayaan suatu masyarakat terhadap sistem yang mereka miliki, sehingga mereka minder dengan sistemnya sendiri dan mengagumi sistem lain. Hal inilah yang menimbulkan kritik interen terhadap sistem kepercayaan, yang dapat melahirkan salah satu di antara dua alternatif yaitu meninggalkan kepercayaan itu kemudian mengadopsi kepercayaan yang dikagumi dan atau melakukan penafsiran terhadap sistem kepercayaan yang dianut berdasarkan kepada sistem kepercayaan yang dikagumi, sehingga terkesan pemaksaan penafsiran dan penakwilan terhadap kepercayaan sendiri.

Walaupun setiap bangsa mempunyai kepercayaan dan sistem yang berbeda, tetapi pandangan manusia secara global mengenai wanita - sebelum turunnya Alqur'an - secara umum menunjukkan persamaan. Sebelum diutusnya Nabi Muhammad saw, perempuan termasuk komunitas tertindas; hak-hak mereka tidak diakui dan martabat mereka diabaikan. Hal ini berlaku secara global, baik di dunia Barat maupun Timur ${ }^{4}$. Kaum perempuan dilihat sebagai kelas dua setelah kaum laki-laki, justru itu mereka diabaikan dan bahkan cenderung ditindas serta diperlakukan sekehendak hati oleh kaum pria Tidak ada sistem yang memberikan pembelaan kepada mereka. Suasana semacam ini menumbuh serta menyuburkan perasaan benci

${ }^{4}$ Kadar M. Yusuf. Pembelaan Alqur'an Kepada Kaum Tertindas. Jakarta; Amzah. 2005., hlm. 66. atau material. Islam tidak menunutut para suami berlaku adil dalam membagi perasaan cinta kasih antar isteri-isterinya, karena memang kaum pria tidak akan pernah bisa membagi perasaan cinta yang persis sama antara setiap isterinya. Tetapi, Islam menuntut agar berlaku adil alam pembagian hal-hal yang bersifat fisik atau mererial. Para suami juga dituntut agar tidak mewujudkan kecenderungan lebih mencintai seorang isteri dari yang lain dalam bentuk pemberian hal-hal yang bersifat material yang melebihi dari isterinya yang laing.

Alqur'an sebagai Kitab Suci dan panduan hidup umat Islam sebenarnya lebih awal melakukan emanspasi perempuan. Ia banyak mengadakan reformasi terhadap sistem yang berlaku di tengah-tengah masyarakat global, khususnya masyarakat Arab. Bahkan Kitab Suci ini berhasil menciptakan opini dan paradigma baru mengenai perempuan menggantikan paradigma lama. Maka tidak mustahil, bahwa ada kemungkinan pemikiran mengenai kaum perempuan di Barat diilham oleh gagasan Alqur'an tetapi telah mereka sekulerkan sebagaimana mereka juga dulu mempelajari ilmu pengetahuan di dunia Islam kemudian mereka bawa kenegeri mereka setelah menghilangkan nuansa keimanan di dalamnya. Emanspasi perempuan alah Alqur'an jauh berbeda dari emanspasi alah Barat, baik dari aspek sasaran maupun gerakan atau penerapannya. Dari aspek sasaran, Alqur'an tidak ingin menyamakan peran perempuan dengan kaum laki-laki secara mutlak. Maka Alqur'an memandang, bahwa laki-laki bukan superior seperti yang dicurigai oleh kaum feminisme alah Barat. Dan dari aspek gerakan dan penerapan, Alqur'an juga tidak menyatakan persamaan kaum perempuan dengan laki-laki secara mutlak. Tetapi, ada hak dan kewajiban yang sama antara laki-laki dan perempuan dan ada pula hak dan kewajiban mereka yang berbeda. Yang pertama adalah hal-hal yang berkaitan dengan individu sebagai hamba Allah, dan yang terakhir hal-hal yang berkaitan dengan hubungan antar lakilaki dan perempuan guna menjaga keutuhan, keseimbangan dan keharmonisan. 
perempuan itu pintu syaitan, dan dia malu dengan kecantikannya karena hal itu merupakan senjata iblis untuk memfitnah dan menggoda ${ }^{9}$. Pandangan semacam ini berimplikasi terhadap paradigma mereka mengenai perempuan, yang cenderung memandang perempuan itu sebagai kelas bawah dan dikucilkan. Bahkan hal itu melahirkan pula ide mengenai "lebih baik membujang daripada kawin".

Dalam tradisi masyarakat Arab Jahiliah - di mana Alqur'an diturunkan - perempuan juga dianggap dan diperlakukan dengan perlakuan yang sama. Mereka tidak diberi hak warisan, secara fisik mereka boleh diwarisi oleh keluarga suaminya apabila suami itu telah meninggal dunia, dan juga diperlakukan penindasan lainnya. Bahkan lebih jauh, di Eropa pada abad ke-6 masehi, perempuan itu diragukan kemanusiaannya, sehingga diadakan komprensi yang khusus membicarakan perempuan; apakah perempuan itu manusia atau bukan? Komperensi itu akhirnya menetapkan, bahwa perempuan itu manusia yang diciptakan hanya semata-mata untuk melayani laki-laki ${ }^{10}$. Di pedalaman Eropa, Asia Tengah dan Afrika Utara dipercayai bahwa tatapan perempuan yang sedang menstruasi mempunyai kemampuan untuk menimbulkan berbagai bencana, yaitu dapat menyebabkan masakan menjadi basi dan gagal panen ${ }^{11}$

Pandangan rendah, negatif atau miring terhadap perempuan berlangsung sangat lama. Di dunia Barat dan Eropa sampai awal abad ke-19 masih memandang rendah terhadap perempuan, dan tidak ada hukum yang memberikan perlindungan kepada kaum perempuan. Suami tidak akan dituntut di muka pengadilan jika dia menyakiti atau menjual isterinya. Mustafa al-Siba`i mengatakan, bahwa undang-

\section{${ }^{9}$ Ibid.}

10 al-Siba i, Mustafa. Al-Mar'ah bayn al-Fiqh wa al-Qānūn. t.tp; al-Makatabah al-`Arabiyah. t.th., hlm. 20.

${ }^{11}$ Nasharuddin Umar. Theologi Menstruasi: Antara Mitos dan Kitab Suci. Jurnal Ilmu dan Kebudayaan; Ulumul Qur'an. No.2, Vol IV th 1995., hlm. 72. laki-laki kepada kaum perempuan. Mereka tidak menginginkan anaknya seorang perempuan. Mereka kecewa dan merasa terhina ketika mendapatkan berita bahwa isterinya melahirkan seorang anak perempuan. Alqur'an mengambarkan sikap mereka ini :

Dan apabila seseorang dari mereka diberi kabar dengan (kelabiran) anak perempuan, hitamlah (merah padamlah) mukanya, dan dia sangat marah. Ia menyembunyikan dirinya dari orang ramai, disebabkan buruknya berita yang disampaikan kepadanya. Apakah dia akan memeliharanya dengan menanggung kehinaan ataukah akan menguburkannya ke dalam tanah (bidup-bidup)? Ketahuilah, alangkah buruknya apa yang mereka tetapkan itus.

Begitu hinanya perempuan dalam pandangan masyarakat Arab Jahiliah, sehingga mereka memperlakukan anak perempuan mereka sendiri lebih hina dari binatang. Ada empat bentuk perlakuan masyarakat Arab terhadap anak perempuan, jika mereka ingin memusnahkannya yaitu 1) menggali lobang lalu mereka menguburnya hingga mati, 2) ada mereka yang melemparkannya dari puncak gunung, 3) membenamkannya ke dalam air, dan atau 4) menyembelihnya ${ }^{6}$. Perbuatan sadis yang mereka lakukan ini dilatarbelakangi oleh kecemburuan, pandangan hina terhadapnya, dan atau takut miskin?

Pandangan terhadap kaum perempuan seperti di atas berlaku di mana-mana dan dalam semua tradisi, termasuk tradisi agama. Dalam agama Yahudi, misalnya, perempuan dianggap sama derajatnya dengan pembantu dan menjadi hak bagi seorang ayah menjualnya bahkan perempuan tidak mempunyai hak warisan ${ }^{8}$. Demikian pula dalam tradisi agama Nasrani, tokoh-tokoh agama ini menganggap

${ }^{5}$ QS (al-Nab);58-59.

${ }^{6}$ Al-Jawi, Muhammad Nawawi. Al-Tafsir al-Munir Jilid I. Bandung; Shirkah al-Ma arif. t.th., hlm. 457.

7 Ibid.

8 Anang Haris Himawan. Teologi Feminisme Dalam Budaya Global; Telaah Kritis Fiqih Perempuan. Jurnal Ilmu dan Kebudayaan; Ulumul Qur'an. No.4/VII/97., hlm. 37.

120 
pengamalan ajaran agama demikian pula balasannya ${ }^{14}$. Tidak ada perbedaan prinsipil kewajiban laki-laki dan wanita, dan tidak ada perbedaan syorga yang dijanjikan untuk laki-laki dan perempuan.

Cara kedua yang dilakukan Islam dalam mereformasi kondisi kaum perempuan adalah melakukan perombakan terhadap sistem yang telah berlaku, seperti sistem perkawinan (akad nikah), talak, dan $i l \bar{a}^{\prime}$.

Alqur'an melakukan prombakan terhadap sistem perkawinan yang berlaku di tengah masyarakat Arab. Dari tujuh model pernikahan yang berlaku di tengah masyarakat Arab, hanya satu model pernikahan yang dilegalkan oleh Islam yaitu model pernikahan yang berlaku sekarang. Dan enam model pernikahan lainnya dilarang, sebab model pernikahan yang enam tersebut merendahkan kaum perempuan. Keenam model pernikahan itu adalah pernikahan syighar ${ }^{15}$, istibda ${ }^{16}$,

${ }_{14}$ Dalam Surat 33 (al-Ahżäb), misalnya, ditegaskan: " Sesungguhnya laki-laki dan perempuan yang muslim, laki-laki dan perempuan yang mu'min, laki-laki dan perempuan yang tetap dalam keta atannya, laki-laki dan perempuan yang benar, laki-laki dan perempuan yang sabar, laki-laki dan perempuan yang khusyu', laki-laki dan perempuan yang bersedekah, laki-laki dan perempuan yang berpuasa, laki-laki dan perempuan yang memelihara kehormatannya, laki-laki dan perempuan yang banyak menyebut (nama) Allah, Allah telah menyediakan untuk mereka ampunan dan pahala yang besar". Jadi, Alqur'an tidak mempunyai pandangan diskriminatif antara laki-laki dan perempuan dalam persoalan tanggung jawab dan balasan atas pelaksanaan tanggung jawab tersebut.

${ }^{15}$ Nikah syighar adalah saling menukar anak perempuan, saudara perempuan, atau budak perempuan tanpa memberikan maskawin. Atau dengan kata lain, seorang laki-laki menikahkan anak, saudara perempuan, atau budak perempuannya dengan laki-laki lain tanpa maskawin, dengan imbalan laki-laki itu menikahkan pula anak atau saudara perempuannya dengan laki-laki tersebut. Artinya, anak, saudara, atau budak perempuan itulah sebagai maskawin atas pernikahan mereka masingmasing.

${ }^{16}$ Istibda' adalah seorang suami membolehkan isterinya bergaul dengan lakilaki lain, kemudian menguzlahnya sehingga dia hamil. undang Inggeris sampai tahun $1805 \mathrm{M}$ masih membolehkan laki-laki menjual isterinya. ${ }^{12}$

\section{Reformasi Qur'ani}

Gagasan yang paling awal memberikan perhatian yang sungguhsungguh dan baik terhadap kaum prempuan adalah berasal Islam. Agama ini memberikan gagasan dan ide-ide baru tentang perempuan. Gagasan dan ide-ide baru itu tidak hanya dalam teori dan konsep, tetapi diujudkan dalam tindakan nyata. Hukum yang di bawanya memberikan perlindungan kepada kaum perempuan, bahkan ajaran Alqur'an tidak hanya membela kaum prempuan saja tetapi juga membela semua kaum tertindas. Banyak kelonggaran (rukhsah) yang diberikan Alqur'an kepada kaum lemah termsuk di antaranya perempuan. Alqur'an mempertanyakan kepada kaum Muhajirin dan Anshar yang ada di Kota Madinah tentang perhatian mereka terhadap kaum lemah yang mereka tinggalkan di kota Mekkah, di mana mereka tidak sanggup hijrah ke Madinah bersama Rasul. Termasuk di antara mereka itu kaum perempuan. Alqur'an menegaskan :

Mengapa kamu tidak mau berperang di jalan Allah dan (membela) orangorang yang lemah baik laki-laki, wanita-wanita maupun anak-anak yang semuanya berdo a: "Ya Tuban kami, keluarkanlah kami dari negeri ini (Mekah) yang zalim penduduknya dan berilah kami pelindung dari sisi Engkau, dan berilah kami penolong dari sisi Engkau!"'13.

Ada dua metode yang dilakukan Alqur'an dalam pembelaannya kepada kaum perempuan. Pertama pembangunan opini dalam rangka menghapus pandangan negatif terhadap perempuan. Hal itu dapat dilihat dalam pernyataan-pernyataan Kitab Suci ini mengenai hak dan kewajiban yang sama antara kaum laki-laki dan perempuan dalam

12 Mustafa al-Siba `i. Al-Mar'ah bayn al-Fiqh wa al-Qānūn. hlm. 20 -21.

${ }^{13}$ QS $4($ al-Nisā); 75. 
tidak halal bagiku selama-lamanya. Akhirnya, turunlah ayat yang membatasi talak itu maksimal tiga kali21.

Talak (yang dapat dirujuki) dua kali. Setelah itu boleh rujuk lagi dengan cara yang ma'ruf atau menceraikan dengan cara yang baik. Tidak halal bagi kamu mengambil kembali dari sesuatu yang telah kamu berikan kepada mereka, kecuali kalau keduanya khawatir tidak akan dapat menjalankan bukumbukum Allah. Jika kamu khawatir bahwa keduanya (suami isteri) tidak dapat menjalankan bukum-hukum Allah, maka tidak ada dosa atas keduanya tentang bayaran yang diberikan oleh isteri untuk menebus dirinya. Itulah bukumbukum Allah, maka janganlah kamu melanggarnya. Barangsiapa yang melanggar bukum-hukum Allah mereka itulah orang-orang yang zalim².

Selain ketentuan mengenai perkawinan dan talak, Alqur'an menrombak tradisi kaum laki-laki di kalangan masyarakat Arab yang suka melakukan ilä'. Said ibn Musayyab mengatakan; ilä adalah cara orang jahiliah menyakiti isterinya. Apabila seorang laki-laki tidak menyukai isterinya lagi dan dia tidak rela isterinya itu menikah dengan laki-laki lain, maka dia meng-ilä́ perempuan tersebut. Kemudian Allah menurunkan ayat 226 smpai dengan 227 , yang membatasi masa ilä itu maksimal hanya sampai empat bulan saja ${ }^{23}$. Jika sudah sampai empat bulan, maka sang suami harus memilih salah satu di antara dua alternatif, yaitu kembali atau menceraikannya.

Itulah reformasi Alqur'an. Ia tidak mensejajarkan secara mutlak antara wanita dan laki-laki, seperti yang diinginkan oleh sebagain kaum feminisme. Penghargaan kepada kaum wanita bukan pada kesejajarannya secara mutlak dengan kaum pria. Bahkan, dalam persoalan ini tidak laiak digunakan istilah kesejajaran tersebut. Sebab istilah itu mengambar komprontasi dan permusuhan. Padahal Islam memandang, dua jenis manusia ini sebagai sahabat yang tidak dapat

21 Al-Wahidi, Abi Hasan Ali. Asbāb al-Nuqūl. Bairut; Dar al-Kutub al-`Ilmi. t.th. hlm. 55.

22 QS 2 (al-Baqarab); 229.

${ }^{23}$ Al-Wahidi, Abi Hasan Ali. Asbāb al-Nu乏ūl., hlm. 54 - 55. baghaya $^{17}$, akbdan ${ }^{18}$, mut'a ${ }^{19}$, dan pernikahan muqt20. Pernikahanpernikahan ini menjadikan wanita seperti barang, justru karenanya Islam melarangnya.

Pembelaan kepada kaum perempuan juga dilakukan dengan membuat ketentuan masa maksimal menunggu bagi seorang perempuan setelah dicerai oleh suaminya (iddah), demikian pula pembatasan talak maksimal hanya tiga kali dan membatasi masa menunggu bagi wanita setelah di-ila' suaminya maksimal hanya empat bulan. Sebelum ketentuan ini diberlakukan, kaum laki-laki dapat berbuat sesukanya terhadap kaum perempuan. Sebelum talak itu dibatasi maksimal tiga kali, seorang suami boleh menceraikan isterinya berapa kalipun yang dia sukai. Al-Wahidi, berdasarkan riwayat Hisyam ibn Urwah, menjelaskan: " Dulu seorang laki-laki boleh menceraikan isterinya kemudian rujuk sebelum habis iddah, walaupun sampai beribu kali. Pada suatu ketika, ada seorang suami menjatuhkan talak isterinya. Setelah iddahnya hampir habis, dia rujuk kemudian menjatuhkan talaknya kembali. Selanjutnya, dia berkata kepada isterinya; "Demi Allah, saya tidak akan melindungi kamu dan kamu

17 Yang dimaksud dengan nikah bagahaya adalah seorang wanita membuat tanda di rumahnya yang menunjukkan bahwa dia siap melavani setiap laki-laki yang ingin mempergaulinya. Jika dia sudah melahirkan maka dia menisbahkan anaknya itu kepada salah seorang laki-laki yang mirip dengan anak tersebut.

18 Nikah akbdan ialah seorang perempuan melakukan hubungan seksual dengan beberapa orang laki-laki. Jika dia sudah hamil, maka dia memanggil semua laki-laki yang mempergaulinya, kemudian menisbahkan anak yang dikandungnya itu kepada salah seorang di antara mereka yang dicintai oleh wanita tersebut.

19 Mut ah adalah nikah kontrak, dimana pernikahan dan hubungan antara suami isteri dibatasi dengan waktu tertenutu sesuai dengan kesepakatan kedua belah pihak.

${ }^{20}$ Nikah muqt adalah pernikahan seorang laki-laki dengan perempuan dengan cara mewarisi perempuan tersebut. 
sering menyebut kebaikan Khadijah walaupun isterinya itu sudah lama meninggal. Nabi mengatakan dalam suatu sabdanya:

$$
\text { خير نسائها خديجة بنت خويلد، و خير نسائها مريم بنت عمران } 25
$$

Artinya: Perempuan yang terbaik adalah Khadijah binti Khuwailid, dan perempuan yang terbaik adalah Maryam binti `Imran.

Dalam Hadis yang lain Nabi juga mengatakan:

$$
\text { حسبك من نساء العالمين مريم بنت عمر أنة ، و خديجة بنت خويلد، وفاطمة بنت محمد، }
$$

Artinya: wanita-wanita terbaik di dunia adalah Maryam binti 'Imran, Khadijah binti Khuwailid, Fathimah binti Muhammad, dan Asiah isteri Fir`un.

Rasul berkata dalam pujiannya kepada Khadijah :

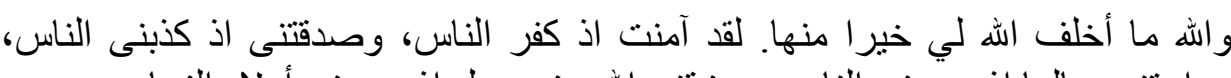

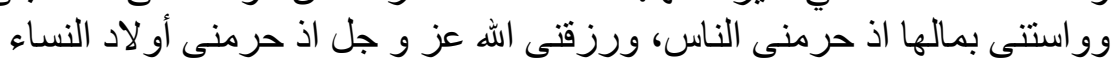

Artinya: Demi Allah, Allah tidak memberikan kepadaku setelahnya yang lebih baik darinya. Dia (Khadijah) beriman ketika orang masih kafir, dia membenarkan aku ketika orang mendustakan aku, dia membantuku dengan hartanya ketika orang mengharamkan bantuan itu terhadapku, dan Allah menganugerahkan anak-anak kepadaku melaluinya ketika aku tidak mendaptkan dari perempuan lainnya.

\section{2. 'A'isyah binti Abu Bakar}

'A'isyah lahir di Mekkah pada tahun ke 4 kenabian dan meniggal pada tahun $58 \mathrm{H} / 678$. 'A'isyah digambarkan sebagai ummul mu'minin (ibu orang-orang mukmin) adalah seorang perempuan yang cerdas. Satu-satunya wanita yang dinikahi Nabi dalam usia anak-anak dan bikir. Dia seorang wanita yang cantik teramat dicintai Nabi. Pernah

${ }^{25}$ Hadis Riwayat al-Tirmizi. Sunan al-Tirmiri, wa Huwa al-Jami al-Shabih Jilid V. t.tp; Maktabah Dahlan. t.th., 367. Hadis ke-3980.

${ }^{26}$ Ibid. Hadis ke -3981. dipisahkan antara satu dari yang lain. Islam memposisikan kaum perempuan sebagai mitra bagi kaum laki-laki, demikian pula sebaliknya; bahwa kaum laki-laki mitra bagi kaum perempuan. Tidak boleh ada yang merasa dirugikan, sebab kedua-kedua mempunyai hak dan kewajiban sama terhadap pasangannya. Alqur'an mengambarkan bunna libās lakum wa antum libās labunna (kaum perempuan pakain bagi kaum pria, dan kaum pria pakaian bagi kaum perempuan ${ }^{24}$. Karena posisinya sebagai pakain bagi yang lain, maka tentu wanita sebagai pakain bagi suaminya tidak mungkin sama dengan suami sebagai pakaian bagi isterinya.

\section{Hasil Reformasi Qur'ani}

Ide dan gagasan Alqur'an mengenai perbaikan terhadap kondisi wanita, baik dalam tataran opini ataupun dalam tataran aktual telah membuahkan hasil. Hal itu, misalnya, tergambar dalam prilaku, budaya, dan kreativitas yang dilakukan oleh para isteri Nabi Muhammad Saw. Mereka merupakan prototype perempuan qur'ani output madrasah nubuwah, yang semestinya dijadikan model oleh perempuan pada masa kini terutama perempuan muslimah. Hal itu terlihat pada kepribadian Khadijah binti Khuwailid dan 'A'isyah binti Abu Bakar.

\section{Khadijah bin Khuwailid}

Khadijah lahir pada abad ke 6 hijrah, sekitar tahun 556 M. dan meninggal tahun $620 \mathrm{M}$. Sebelum dinikahi Nabi, Khadijah telah menikah dua kali yaitu pertama dengan 'Atiq bin `Abid bin Mahzum. Kemudian setelah bercerai, dia nikah lagi dengan Abu Halah. Setelah Abu Halah meninggal, Khadijah dilamar oleh banyak laki-laki tetapi lamaran itu ditolaknya. Khadijah merupakan wanita yang pertama dinikahi Nabi Saw. Dia tidak menikahi perempuan lainnya kecuali setelah Khadijah meninggal dunia. Nabi sangat menyintainya, dia

\footnotetext{
${ }^{24}$ QS 2 (al-Baqarab); 187.
} 
feminisme? Jika kritikan itu diarahkan terhadap Hadis ahad mungkin masih dapat dipahami, sebab Hadis ahad masih ₹ anny al-wurüd. Tetapi, bagaimana dengan Hadis mutawatir dan Alqur'an yang tidak diragukan laki keabsahannya, dan bahkan di antara nash tersebut memiliki makna yang pasti (qath $i$ al-dalalab)?. Bagaimanapun juga, terdapat banyak ayat yang memang mengambarkan perbedaan antara laki-laki dan perempuan dalam kasus-kasus tertentu, seperti saksi. Satu orang saksi dari kalangan laki-laki sama dengan dua orang saksi dari kalangan wanita ${ }^{27}$. Demikian pula talak (perceraian), dimana ia hanya dianggap sah jika diucapkan oleh suami. Kaum feminisme bisa saja berdalih atas nama penafsiran baru bukan kritikan terhadap Kitab Suci. Tetapi, ayat-ayat itu diungkapkan dengan makna yang jelas yang tidak mengandung kemungkinan makna lain.

Gerakan emanspasi perempuan sepantasnya melanjutkan pola dan model emanspasi yang dilakukan Alqur'an. Kitab Suci ini dengan gagasan dan hukum yang dikandunginya berusaha mengangkat derajat kaum perempuan. Banyak nas syar $i$ yang mengambarkan urgensi kaum wanita dalam kehidupan umat manusia. Hal itu seperti pemberian hak waris kepada kaum perempuan, yang sebelumnya hak waris itu hanya dimonopoli oleh kaum pria. Alqur'an juga menghapus sistem pewarisan wanita, yang sebelumnya perempuan itu diperlakukan seperti harta pusaka, yaitu diwarisi jika suaminya telah meninggal 28 .

Jika Islam menghendaki emansipasi wanita seperti yang diinginkan oleh gerakan kaum feminisme, maka tentu sejak dari awal Alqur'an sudah melakukan hal itu. Sebab, banyak perubahan yang amat tajam yang dilakukan Alqur'an baik dalam membangun opini masyarakat maupun membuat ketentuan mengenai kaum wanita, maka tentu saja Islam bisa menetapkan kesejajaran mutlak antara laki-laki dan wanita. Tetapi Islam tidak melakukannya. Ini bermakna, bahwa digambarkan, ya 'A'isyah bubbuki fi qalbi kal 'urwatil wutsqa (Hai 'A'isyah, cintamu di hatiku bagaikan tali yang kokoh), yaitu innaha 'ala baliba lam yataghayyar wa lam yatabaddal (keadaannya tidak pernah berubah dan tidak pernah tergantikan). Ada beberapa hal yang dapat dipelajari dan teladani oleh para ibu dari sosok ummul mu 'minin ini, yaitu :

a. 'A'isyah seorang wanita yang sangat sabar dalam menerima ujian yang teramat berat sekalipun, seperti kesabarannya ketika difitnah oleh Abdullah bin Ubay bin Salul.

b. Dia yang sangat `alim dan menyintai ilmu pengetahuan

c. Dia sangat zuhud, rajin beribadah, dan termat takut kepada Allah

d. Dia sangat suka membantu dan menolong orang. Harta yang dimilikinya selalu atau banyak diberikannya kepada yang membutuhkan. 'A'isyah memiliki sifat kesetiakawanan sosial. Dalam suatu riwayat disebutkan, bahwa 'A'isyah pernah mendapat hadiah dari Mu awiyah berupa kalung emas, padanya terdapat mutiara seharga seratus ribu. Hadiah itu dibagibagikannya kepada para isteri Nabi lainnya

Kedua isteri Nabi di atas, termasuk isteri Nabi Muhammad lainnya, merupakan sosok produk atau out put emansipasi qur'ani terhadap kaum perempuan. Maka emanspasi perempuan bukanlah menyamakannya secara mutlak dengan kaum pria, karena kedua jenis insan ini tidak mungkin disamakan. Emansipasi qur'ani bermakna pemberdayaan terhadap mereka, dalam bentuk perbaikan moral, perlakuan secara adil, penghapusan pelacuran, dan yang terpenting lagi membuat mereka mencintai ilmu pengetahuan serta menimba ilmu itu. Sebagaimana, Ummul Mukminin 'A'isya RA mencintai dan mengembangkan ilmu tersebut.

\section{Pelestarian dan Kelanjutan}

Yang menjadi persoalan di sini adalah apakah kita umat Islam harus mengkritik nas-nas syar ${ }^{\prime} i$ yang telah mapan itu atas alasan 128 
Alqur'an lebih kepada mitra atau kerjasama, di mana keduabelah pihak tentu tidak mungkin mempunyai tugas dan kewajiban yang sama, karena mitra atau kerjasama hanya terjadi dengan tugas dan kewajiban yang berbeda.

Justru itu, emansipasi wanita lebih tepat diarahkan kepada peningkatan kerjasama itu, dengan memberikan pemahaman dan kesadaran mengenai hak dan kewajiban masing-masing. Selain itu, pembelaan kepada kaum perempuan lebih diarahkan kepada penanaman nilai-nalai qur`ani terhadap mereka sehingga mereka terbebas dari gangguan yang dapat mengotori kesuciannya.

\section{Bibliografi}

Anang Haris Himawan. Teologi Feminisme Dalam Budaya Global; Telaah Kritis Fiqih Perempuan. Jurnal Ilmu dan Kebudayaan; Ulumul Qur'an. No.4/VII/97.

Didin Syafruddin. Argumen Supremasi atas Perempuan Penafsiran Klasik QS al-Nisä': 34. Jurnal Ilmu dan Kebudayaan; Ulumul Qur'an. Nomor 5 dan 6, Vol V. 1994. Edisi Khusus 5 tahun UQ.

Ḥijāzi, Muhammad Mạ̣mūd, Al-Tafsìr al-Wādhih $\square$, Bairut, Dār al-Jayl, 1993

Ibn Katsīr, 'Imād al-Dīn Abī al-Fidā’ Isma`il, Tafsìr al-Qur'ān al'Az̧him, Bandung, Shirkah Nur Asia, tth.

al-Jawi, Muhammad Nawawi. Al-Tafsir al-Munir Jilid. Bandung; Shirkah al-Ma arif. t.th.

Kadar M. Yusuf. Pembelaan Alqur'an Kepada Kaum Tertindas. Jakarta; Bumi Aksara. 2005

al-Maraghī, Ahmad Mustafā, Tafsìr al-Maräghì, Bairut, Dar al-Fikr, 1974.
Islam tidak menghendaki persamaan mutlak. Yang diinginkan Islam adalah kerjasama dan kemitraan yang harmonis antara kaum pria dan wanita. Yang memang masing-masing mereka mempunyai tugas dan fungsi yang berbeda, yang bertujuan untuk mewujudkan keharmonisan dan kelanggengan berdua.

Penghargaan kepada kaum wanita adalah pelestarian nilai-nilai qur'ani dalam kehidupan kaum wanita, seperti penghapusan prostitusi dan menanamkan kesadaran dalam diri para suami agar tidak melakukan tindakan kekerasan dalam rumah tangga. Hal itu seperti yang diajarkan Alqur'an :

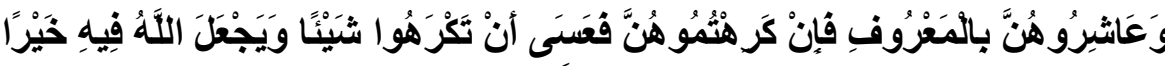 \\ كَثيرًا}

Maksudnya: Dan bergaullah dengan mereka secara patut. Kemudian bila kamu tidak menyukai mereka, (maka bersabarlah) karena mungkin kamu tidak menyukai sesuatu, padahal Allah menjadikan padanya kebaikan yang banyak ${ }^{29}$.

Selain itu, emansipasi juga bermakna pemberdayaan perempuan melalui pendidikan dan pelatihan serta melahirkan kebijakan dalam rangka pemberdayaan terhadap mereka.

\section{Penutup}

Perubahan yang diinginkan Alqur'an terhadap kondisi kaum perempuan bukan persamaan mutlak antara kaum pria dan kaum perempuan. Bagaimanapun juga, Alqur'an tetap memandang masing-masing keduanya mempunyai tugas dan fungsi yang berbeda. Keduanya mesti menjalankan fungsi dan tugasnya masing-masing, untuk keharmoisan dan kebahagiaan bersama. Maka perbedaan gender dalam Alqur'an tidak bersifat diskriminatif negatif seperti yang dituduhkan oleh kaum feminisme. Pembedaan gender dalam 
Al-Fikra: Jurnal Ilmiah Keislaman, Vol. 11, No. 1, Januari-Juni 2012

Nasharuddin Umar. Theologi Menstruasi: Antara Mitos dan Kitab Suci. Jurnal Ilmu dan Kebudayaan; Ulumul Qur'an. No.2, Vol IV th 1995.

Shāwi, Ahmad, Al-Shāwi 'Alā al-Jalälayn, ttp, al-Bāby al-Halabi, th. al-Shābuni, Muhammad `Ali. Shafwah al-Tafäsìr. Bairut; Dar al-Jayl. t.th al-Siba i, Musthafa. Al-Mar'ah bayn al-Figh wa al-Qānūn. t.tp; alMakatabah al-'Arabiyah. t.th.

al-Tirmizi, Abi Isa Muhammad bin Isa bin Surah. Sunan al-Tirmiži. Bandung; Maktabah Dahlan. t.th.

al-Wahidi, Abi Hasan Ali. Asbäb al-Nuそūul. Bairut; Dar al-Kutub alIlmi. t.th. 